TITLE:

CONSIDERATIONS ON THE

TAXONOMIC STATUS OF THE

LANCELETS OF THE GENUS

BRANCHIOSTOMA FROM THE JAPANESE WATERS

$\operatorname{AUTHOR}(\mathrm{S})$ :

Nishikawa, Teruaki

CITATION:

Nishikawa, Teruaki. CONSIDERATIONS ON THE TAXONOMIC STATUS OF THE LANCELETS OF THE GENUS BRANCHIOSTOMA FROM THE JAPANESE WATERS. PUBLICATIONS OF THE SETO MARINE BIOLOGICAL LABORATORY 1981, 26(1-3): 135-156

ISSUE DATE:

1981-03-30

URL:

http://hdl.handle.net/2433/176018

RIGHT: 


\title{
CONSIDERATIONS ON THE TAXONOMIC STATUS OF THE LANGELETS OF THE GENUS BRANCHIOSTOMA FROM THE JAPANESE WATERS ${ }^{1)}$
}

\author{
Teruaki NISHIKAWA \\ Biological Laboratory, College of General Education, Nagoya University
}

With Text-figures $1-5$ and Tables 1-4

\section{Introducton}

The lancelets are generally called by Japanese "Namekuji-uo" (Namekuji=slung, $u o=$ fish); at the same time, however, this Japanese name has been applied also to the single species usually referred to Branchiostoma belcheri (Gray, 1847) since about 1922 when the taxonomic discussions on Japanese lancelets were seemingly closed as seen in the historical paragraph of the present paper. The inclusion of all Japanese lancelets in the same single species may be acceptable only when some differences found among the specimens of "Namekuji-uo" from different localities in this country are recognized to be of the intraspecific variation. On the other hand, the lancelets from Kiaochow Bay on the southern coast of Shantung Peninsula, North China, were distinguished as a distinct variety in 1936 from the typical form of $B$. belcheri, further it was found that this variety was related closely to the "Namekuji-uo" occurring generally along the Japanese coasts except the west coast of Kyusyu Island. Evidently, this seems to request the detailed taxonomic re-examination of Japanese lancelets. The study will need a number of specimens from different localities in this country.

Unfortunately, however, "Namekuji-uo" has been becoming rapidly rarer and rarer in Japan in these days, though it ever occurred in some waters so richly that it was taken as a kind of sea foods as well as in China-this is the story when the coastal water was still clean in this country. Thus, it was urged to collect large material from localities as many as possible. The efforts payed by the present author for several years brought here the material consisting of more than 150, inclusive of 15 "giant larvae" and a considerable number of specimens from Amoy. The present material can never be satisfactory, but seemingly this might be the limit of efforts to the present author in these days when the coastal waters are affected heavily by pollution in this country and "Namekuji-uo" is disappearing from the former localities recorded. Thus, in this paper it is planned to give the results of close

1) Contributions from the Seto Marine Biological Laboratory, No. 672.

Publ. Seto Mar. Biol. Lab., XXVI(1/3), 135-156, 1981. (Article 7) 
examination mainly of the meristic characters on the material after the brief retrospection of the research history of Japanese lancelets.

The present material, one half came from the collections of Tokyo and Kyoto Universities, while the other half from many laboratory collections or private ones. Especially, the actual work of the present studies may be said to be triggered by supply of both living and preserved specimens from Dr. Shin'ichiro Fuse, together with his consistant encouragement, of the Seto Marine Biological Laboratory in the very early stage of the studies. Messrs. Chuichi Araga, Hidetomo Tanase and Torao Yamamoto of the same laboratory, Dr. Osami Tabeta of Shimonoseki University of Fisheries, Mr. Hiroshi Goto of Yuraminato Junior High School, and Mr. Takuya Mori of Toba Aquarium gave the author precious information; and Prof. Eiji Harada and other members of the laboratory gave the author many helpful advices through discussions. Drs. Heizaburo Katayama and Koji Hoshino, and other members of the Mukaishima Marine Biological Laboratory, Hiroshima University helped the author in every way to collect specimens in the waters around that laboratory. To the all gentlemen mentioned above as well as to those who afforded the author every facilities to examine the specimens of Japanese (and some Chinese) lancelets in the collection of their institutions or laboratories, or in their own collections, the author would like to express his hearty thanks. His sincere thanks are due also to Dr. Takasi Tokioka, the former director of the Seto Marine Biological Laboratory, who was so kind to read the manuscript and give many suggestions.

\section{The material examined}

The material examined for the present study consists of the specimens included in the following 20 collections.

A. The collection in the University Museum, University of Tokyo, through the courtesy of Drs. Torao Satoh and Kenji Mochizuki of the museum.

1. Reg. No. 26632: 5 inds., near the estuary of River Miya, Gamagori, Aichi Pref., Mr. Kinroku Taniuchi coll.

2. Reg. No. 10516: 10 inds., near Tadaumi(?), Mihara, Hiroshima Pref., Mr. Kazuki Sawahara coll.

3. Reg. No. 1433: 3 inds., Bungo Channel, between Shikoku and Kyusyu, Dr. Matsubara coll.

4. Reg. No. 1430: 4 inds., Ariake Sea, about $4 \mathrm{~km}$ off Tegama, Omuta, Fukuoka Pref., collected on the sandy flat, 15-18 cm deep, Apr. 1, 1904.

5. Reg. No. 18203: 2 inds., ?Ariake Sea, coll. by Fisheries Experimental Station of Fukuoka Pref.

6. Reg. No. 13521: 15 inds., Amoy.

7. Reg. No. 11554: 30 inds., "China".

8. Reg. No. 15043: 30 inds., "China".

B. The collection in the Zoological Institute, Faculty of Science, Kyoto University, through the courtesy of Drs. Jiro Ikeda and Motoo Tasumi of the faculty. 
1. Nineteen inds., Sumoto-ohama, eastern coast of Awaji Island, Feb. 15, 1912.

2. Two inds. dried up completely, Tomo, near Fukuyama, Hiroshima Pref., Prof. Tamiji Kawamura coll.

3. Two inds., Amakusa, Dr. Aida coll.

4. Five inds., Amoy, Mr. Y. M. Tung coll.

G. The collection in Yoshida College of Kyoto University, through the courtesy of Dr. Saburo Nishimura of the college.

1. Six inds., Ariake Sea, 1903.

2. Five inds., Amoy, presented by Prof. Ichisada Miyazaki of Amoy University, May 27, 1923.

D. The collection of Mr. Hisashi Yokoyama, a graduate student of Kyoto University. Thirteen inds., from three stations off Kojima and Toyokuni-zaki, Tanagawa, Osaka Pref., 27.5-35 $\mathrm{m}$ deep, sand with shell fragments, mud temp. $18.2-19.8^{\circ} \mathrm{C}$, May 1978.

E. The collection of Mr. Shigeki Takamori of the Naikai Regional Fisheries Laboratory.

1. A single ind., Onomichi Strait, Seto Inland Sea, Sept. 20, 1977.

2. A single ind., Onomichi Strait, July, 1978.

3. Eleven inds., Shikanose, Harima-bada, Seto Inland Sea, Sept. 7, 1978.

F. The collection in the Amakusa Marine Biological Laboratory of Kyusyu University, through the courtesy of Dr. Taiji Kikuchi of the laboratory. Ten inds., at "Kyusyu Univ. Invest. Stn. A-13", off Shimabara, Ariake Sea, $50 \mathrm{~m}$ deep, shell sand, Dr. Tanaka and Mr. Nojima coll., Sept. 25, 1977.

G. The collection of Dr. Fuse.

1. A single ind., Maruyama, western coast of Awaji Island, less than $10 \mathrm{~m}$ deep, 1975.

2. A single ind., Nishiwaki, Sakaide, Kagawa Pref., Mar. 1976.

3. A single ind., near Fukura, southern coast of Awaji Island, 8-9 m deep, coll. by Fisheries Experimental Station of Hyogo Pref., Feb. 3, 1976.

H. The collection of Dr. Tokioka: A single ind., south to Jinooshima Island, Wakayama Pref., $35 \mathrm{~m}$ deep, sand, Dr. Denzaburo Miyachi coll., Nov. 19, 1938.

I. The collection of Dr. Minoru Imajima of National Science Museum, Tokyo. Three inds., off the estuary of River Nyugawa, Ehime Pref., Mr. Shinohara coll.

J. The collection in the Seikai Regional Fisheries Laboratory, through the courtesy of Mr. Yoichi Shojima of the laboratory. Two inds., north to Shikanoshima, Fukuoka Pref., $33^{\circ} 50.2^{\prime} \mathrm{N}$ and $130^{\circ} 14.2^{\prime} \mathrm{E}, 50 \mathrm{~m}$ deep; these specimens were described by Shojima in 1974.

K. The collection in the Misaki Marine Biological Laboratory of Tokyo University, through the courtesy of Dr. Michio Shigei of the laboratory. Three inds., outside the inlet of Mito, Misaki, by dredge, July 25, 1933.

L. The collection in the Shimoda Marine Research Center of the University of Tsukuba, through the courtesy of Dr. Toshiki Makioka. A single ind., off Akamatsujima Islet, Nabeta Bay, Shimoda, trawled by Messrs. Nakamura, Ueda, 
Suzuki and Dr. Makioka, 12-13 m deep, July 14, 1972.

M. The collection of Dr. Kenji Mochizuki. A single ind., coast of Suma, Kobe, several meters deep, Nov. 1977.

N. The collection of Osaka Museum of Natural History, through the courtesy of Mr. Ryohei Yamanishi of the museum. A single ind., near Uryu-jima Islet, Saizaki, Mihara, Hiroshima Pref., Mr. K. Matsumoto coll., May 20, 1959.

O. The collection in the Usa Marine Biological Laboratory of Kochi University, through the courtesy of Dr. Mitsuaki Nakauchi of the laboratory. A single ind., Uranouchi Bay, before 1963.

P. The collection in the Biological Laboratory, College of General Education, Nagoya University: A single ind., Miya-oshima, Gamagori, Aichi Pref., by dredge, Prof. Takaoka coll., 1948.

Q. The collection made by benthos survey group of Tanabe Bay in the Seto Marine Biological Laboratory. Three inds., respectively at the following stations: Stn. 2, $27.2 \mathrm{~m}$ deep, sand mud temp. $15.8^{\circ} \mathrm{C}$, Feb. 21, 1978; Stn. 3, $34.5 \mathrm{~m}$ deep, mud with shell fragments, mud temp. $14.2^{\circ} \mathrm{C}$, Feb. 21, 1978; Stn. 5, $22.3 \mathrm{~m}$ deep, mud with shell fragments, mud temp. $24.2^{\circ} \mathrm{C}$, Nov. 1, 1977. The last two specimens were described by Nishikawa in 1978.

R. The author's collection. A single ind., off Hosojima Island near Onomichi, Hiroshima Pref., $12 \mathrm{~m}$ deep, shell sand, May 27, 1975.

S. The collection of Mr. Hiromichi Imakigi, a graduate student of Kyusyu University. Four inds., between Ainoshima Islet and Koga, Fukuoka Pref., $15 \mathrm{~m}$ deep, Nov. 1, 1976.

T. The collection of Dr. Ryonosuke Kitamori. Five inds., off Gobo, Wakayama Pref., ca. $20 \mathrm{~m}$ deep, Apr. 1978.

\section{The Outline of the Research History of Japanese Lancelets}

The following stories are concerned limitedly with the lancelets found in Japan and indicated by Japanese specific name of "Namekuji-uo".

The first finding of lancelets by modern biologists from the Japanese waters was, according to Prof. Kakichi Mitsukuri (Andrews, 1895, pp. 102-103; also see Oka, 1895, p. 133), made in 1881 by Prof. Namie Ishikawa and Mr. Shin'nosuke Matsubara; Ishikawa found some larvae in the plankton samples collected by surface towing near Tomo, Hiroshima Prefecture in summer and Matsubara obtained lancelets by dredge off "Buzen", the northeastern part of Kyusyu, facing the Seto Inland Sea. Since then, many localities of this animal have been recorded in the Japanese waters by many authors (see Table 1 and Figure 1), though many of them have seemingly become to be only the historical records and lost their actual significance at the present day; this may remind the readers of the sudden decrease of "Amphioxus" since the 1930's in the Bay of Naples (Bone, 1958, p. 1).

In taxonomy: Andrews (1895) examined six specimens of "Namekuji-uo" collected from Shikanoshima and identified them "provisionally" with B. belcheri. Later, 


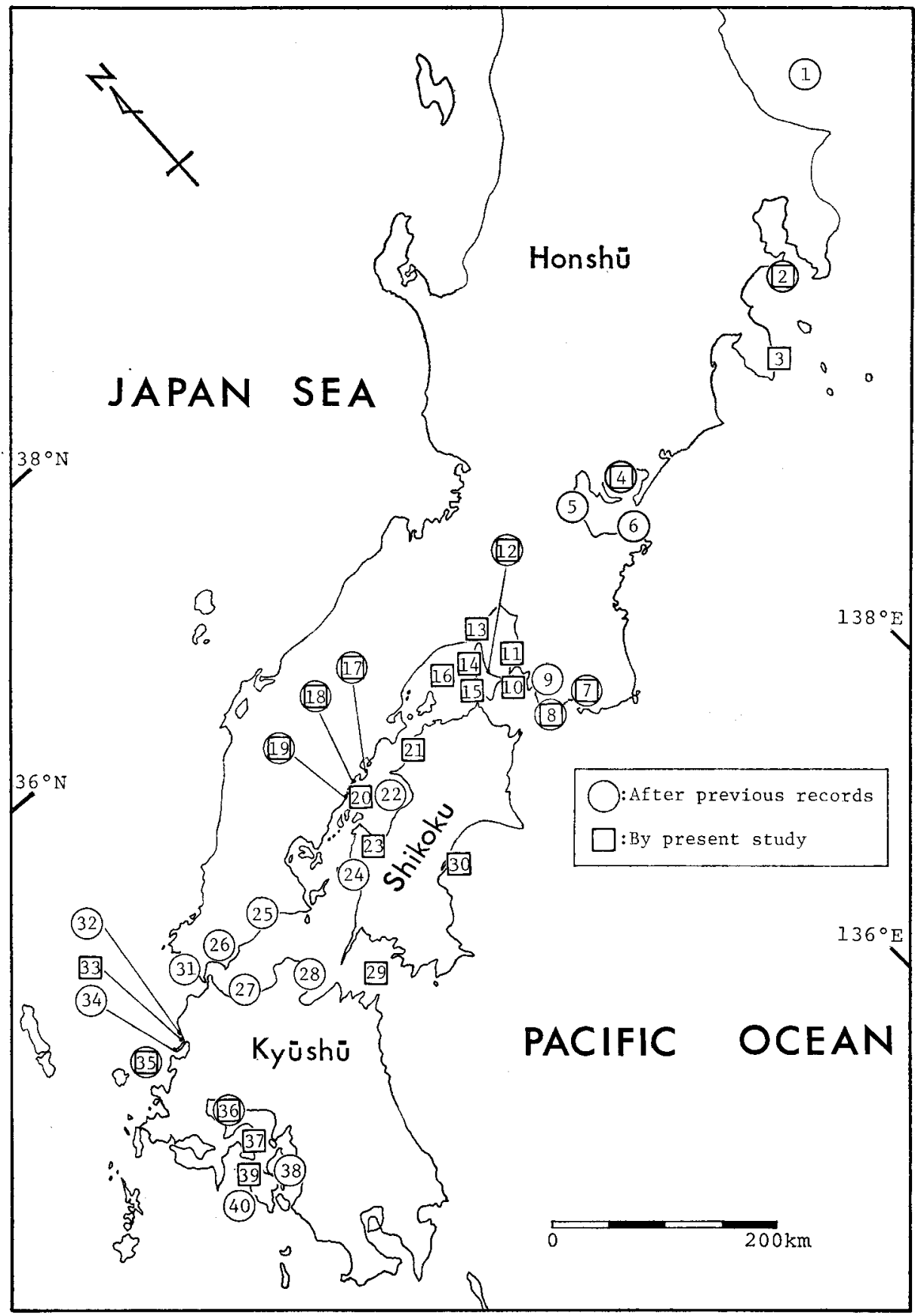

Fig. 1. Localities of "Namekuji-uo" in the Japanese waters. 
Table 1. Localities of "Namekuji-uo" after previous records. For the locality number, see Figure 1.

\begin{tabular}{|c|c|c|c|c|}
\hline $\begin{array}{l}\text { Locality } \\
\text { number }\end{array}$ & Station of Localities & Depth, nature of floor and etc. & Date of Collection & Sources \\
\hline 1 & Off Ibaraki Pref.; $35^{\circ} 58^{\prime} 50^{\prime \prime} \mathrm{N}, 140^{\circ} 50^{\prime} 50^{\prime \prime} \mathrm{E}$. & $57 \mathrm{~m}$ & & Okada, 1929 \\
\hline 2 & Koajiro Bay, Misaki. & $12 \mathrm{ftms}$ & June, 1899 & Kobayashi, 1979 \\
\hline 2 & Koajiro Bay, Misaki. & $\begin{array}{l}\text { (type specimens of } B . \text { nakagawae) Kumakichi } \\
\text { Aoki coll. }\end{array}$ & & $\begin{array}{l}\text { Jordan \& Snyder, } \\
1901\end{array}$ \\
\hline 2 & Off Moroiso, Misaki. & $15 \mathrm{ftms}, 1$ ind. & 1932 & $\begin{array}{l}\text { Shigei, personal } \\
\text { information }\end{array}$ \\
\hline 4 & $\begin{array}{l}\text { Miya-oshima (Mikawa-oshima), Gramagori, } \\
\text { Aichi Pref. *1 }\end{array}$ & Two inds., Takeuchi coll. & $\begin{array}{l}\text { Mar. and May, } \\
1968\end{array}$ & $\begin{array}{l}\text { School Board of } \\
\text { Gamagori, } 1970\end{array}$ \\
\hline 5 & Kawage, Mie Pref. & $\begin{array}{l}\text { Some ones found washed ashore after heavy } \\
\text { storm }\end{array}$ & June, 1914 & Tanaka, 1916 \\
\hline 6 & Off Toba, Mie Pref.; $35^{\circ} 32^{\prime} \mathrm{N}, 136^{\circ} 52^{\prime} \mathrm{E}$. & $16 \mathrm{~m}$, sandy mud & 1976 & $\begin{array}{c}\text { Mori, personal } \\
\text { information }\end{array}$ \\
\hline 7 & Tanabe Bay & 22.3-34.5 m, mud with shell fragments & $\begin{array}{l}\text { Nov. 1,'77 and } \\
\text { Feb. 21, '78 }\end{array}$ & Nishikawa, 1978 \\
\hline 8 & Off Gobo, Wakayama Pref. & $\begin{array}{l}17.3 \mathrm{~m} \text {, sand or sandy mud, } 6 \text { inds. by bottom } \\
\text { sampler }(20 \mathrm{~cm} \times 20 \mathrm{~cm})\end{array}$ & Apr. 22, 1978 & $\begin{array}{l}\text { Wakayama Pref., } \\
1978\end{array}$ \\
\hline 9 & Yura Bay, Wakayama Pref. & The last collection in 1968 & & $\begin{array}{c}\text { Goto, personal } \\
\text { information }\end{array}$ \\
\hline 12 & Sumoto, eastern coast of Awaji Island & Many found washed ashore & Feb. 15,1912 & Tanaka, 1915 \\
\hline 17 & Around Tomo, near Onomichi, Hiroshima Pref. & Larvae by surface towing & summer of 1881 & $\begin{array}{l}\text { Andrews, 1895; Oka, } \\
1895\end{array}$ \\
\hline 17 & Tomo and around Hashiri-jima Island & Ohwatari coll. & Oct., 1909 & Yatsu, 1909 \\
\hline 17 & $\begin{array}{l}\text { Tomo, around Hashiri-jima and Sesui-jima } \\
\text { Islands }\end{array}$ & $\begin{array}{l}\text { more than } 1 \mathrm{ftm} \text {, fine sand, found rather } \\
\text { densely }\end{array}$ & Oct., 1909 & Kobayashi, 1910 \\
\hline 18 & Onomichi, Hiroshima Pref. & H. Iijima & Dec. 6,1900 & Yatsu, 1901 \\
\hline 19 & $\begin{array}{l}\text { near Uryu-jima Island (Nouji sand bank), } \\
\text { Saizaki, Mihara, Hiroshima Pref, } * 2\end{array}$ & Inhabited rather densely & 1938 & Sakata, 1939 \\
\hline 19 & Saizaki, Mihara, Hiroshima Pref. & & Mar. and May, '55 & Nogusa, 1957 \\
\hline 22 & Hiuchi-nada, Seto Inland Sea & ca. $50 \mathrm{~m}$ & & Kikuchi, 1977 \\
\hline 24 & Gogoshima Island, off Matsuyama, Ehime Pref. & Four inds. by dredge & Aug., 1900 & Kataoka, 1900 \\
\hline 24 & Gogoshima Island. & $\begin{array}{l}\text { sandy beach, in the lower intertidal zone, } \\
2 \text { inds. Kataoka coll. }\end{array}$ & June, 1904 & Yatsu, 1904 \\
\hline 25 & $\begin{array}{l}\text { Around Nishinoshima Islet off Tonda, near } \\
\text { Tokuyama, Yamagichi Pref. }\end{array}$ & 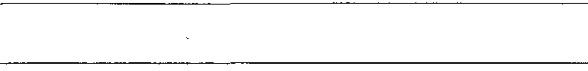 & Apr. 12,1910 & Fujitani, 1910 \\
\hline
\end{tabular}




\begin{tabular}{|c|c|c|c|c|}
\hline 26 & Off Motoyama, near Ube, Yamaguchi Pref. & coarse sand, inhabited rather densely & & Kumada, 1936 \\
\hline 27 & Off "Buzen", Fukuoka Pref., Seto Inland Sea & S. Matsubara coll., by dredge & 1881 & Andrews, 1895 \\
\hline 28 & Off "Bungo"' (=Ooita Pref.) & S. Matsubara coll. & & $\begin{array}{l}\text { Jordan \& Snyder, } \\
1901\end{array}$ \\
\hline 31 & Near Shimonoseki, Yamaguchi Pref. & $\begin{array}{l}\text { "Prinz Adalbert" Expedition coll. (Berlin Mus. } \\
\text { No. 2308) }\end{array}$ & . & Franz, 1922 \\
\hline 32 & Off 'Tsuyazaki, Fukuoka Pref. & $10-25 \mathrm{~m}$ & & Kikuchi, 1977 \\
\hline 34 & Near Shikanoshima, Fukuoka Pref. & ca. $10 \mathrm{ftms}, 2$ inds. & Apr., 1890 & Anonym, 1890 \\
\hline 34 & do. & $10-15 \mathrm{ftms}$, coarse sand, 7 inds. & Aug., 1890 & Nakamura, 1890 \\
\hline 34 & do. & S. Hatta coll. & Apr., 1893 & Andrews, 1895 \\
\hline 34 & do. & Nakagawa coll., by dredge & $1892-3 ?$ & do. \\
\hline 34 & Between Shikanoshima and Tsukuejima Islands & by dredge & Nov., 1894 & Ogura, 1895 \\
\hline 34 & Shikanoshima & 12 inds, from stomach content of mackerels & Summer of 1894 & Takachiho, 1895 \\
\hline 35 & North to Shikanoshima; $33^{\circ} 50.2^{\prime} \mathrm{N}, 130^{\circ} 14.2^{\prime} \mathrm{E}$. & $50 \mathrm{~m}, 2$ inds. & Feb. 6, 1969 & Shojima, 1974 \\
\hline 36 & Ariake Sea, off Tegama, Oomuta, Fukuoka Pref. & on beach at ebb tide, 9 inds. in an hour. & Apr. 1, 1904 & Azuma, 1904 \\
\hline 36 & $\begin{array}{l}\text { Takatsu shallow, off the estuary of River } \\
\text { Okihata, Yanagawa, Ariake Sea }\end{array}$ & ca. 100 inds. & Apr. 18, 1927 & Ohshima, 1927 \\
\hline 36 & $\begin{array}{l}\text { Ara-tsu and Gando-tsu shallows in the northern } \\
\text { part of Ariake Sea }\end{array}$ & exposed only at the low water of spring tide & spring of 1940 & $\begin{array}{l}\text { Oyama \& Yoshii, } \\
1940\end{array}$ \\
\hline 38 & Goshono-ura, Amakusa & $6-10 \mathrm{ftms}$, coarse sand, rather densely inhabited & $1893-97$ & Nakagawa, 1897 \\
\hline 38 & do. & ca. $10 \mathrm{ftms}$, shell sand & $1902 ?$ & Tsukiyama, 1902 \\
\hline 40 & Tomioka Bay, Amakusa & & & Kikuchi, 1977 \\
\hline
\end{tabular}

*1: This locality, discovered by the late Mr. Kinroku Takeuchi in 1934, was designated by the Government to a natural monument on Mar. 27, 1941. Unfortunately, however, no lancelets were collected during the census surveys that were made in June and December, 1968 and in May, 1969 to learn the state of "Namekuji-uo" at the locality in those days (School Board of Gamagori, 1970: A report on the collection survey of "Namekuji-uo" around Mikawa-oshima).

*2: This locality was also designated by the Government to a natural monument. According to Mr. Akasaka of the School Board of Mihara (personal communication of Apr., 1977), however, the environment around the Nouji sand bank has been damaged mainly by scooping up of sand in a large scale for commercial purpose and thus this animal can hardly be found at the present.

The author would like to express his hearty thanks to Mr. Harada of the School Board of Gamagori and Mr. Akasaka of the School Board of Mihara, for these important informations. 
Nakagawa (1897) examined many specimens from Goshono-ura, Amakusa, recognized that 1) the buccal cirri were invariably about 41 within the range of the body length from 26 to $46 \mathrm{~mm}$ (judging from his Table III), 2) the branchial arches increased remarkably with growth within the same range of the body length, and 3) the formula (=-arrangement of myotomes) was 36 to $37,17,10$ to 11 and its variation was "not in accordance with the size of the animal" (ranging from 10.5 to $54 \mathrm{~mm}$ long), and concluded on those features that the specimens from Goshono-ura could not be referred to any of the previously known species, though the erection of a new species for these specimens was impossible for lack of sufficient information about the morphological variations in each of the known species. Willey (1897) separated "the Japanese Amphioxus" described by Andrews (1895) from the type form of Amphioxus belcheri as a variety that was named by him var. japonicus (p. 220, foot note) for the "geographische Merkmale" (Lönnberg, 1901, p. 240), while Jordan and Snyder (1901) erected a new species Branchiostoma nakagawae for the specimens from Koajiro Bay, Misaki and included the specimens described by Andrews (1895) and Nakagawa (1897) within this new species. B. nakagawae was, however, synonymized with Amphioxus japonicus Willey by Lönnberg (1901, pp. 240-241) on the rule of priority. On the other hand, Tattersall (1903), comparing B. nakagawae with $B$. belcheir from Ceylon, came to the conclusion that the two species are "really the same" and the former is a junior synonym of the latter which is "merely a variety of B. lanceolatum". Jordan, Tanaka and Snyder (1913) referred the Japanese name "Namekuji-uwo" $(u w o=u o)$ to B. belcheri inclusive of B. belcheri japonicus and B. nakagawae. Later both Franz (1922) and Hubbs (1922a) synonymized, in their monographs, all specific names given to Japanese lancelets by the above-mentioned descriptions with belcheri. Since then, some of the authors or rather compilers of Japanese books or illustrated catalogues adopted the specific name of japonicum for "Namekuji-uo" (for instance, Tanaka, 1927; Okada, Uchida and Matsubara, 1935; Tokioka, 1947), while others the name of belcheri (or, erroncously, belcherii) (for example, Iijima, 1918; Oyama and Yoshii, 1940; Matsubara, 1955; Tokioka, 1965); but these are taxonomically quite insignificant, because they are not specialists about this animal group.

In biology: Only a few biological or ecological studies of "Namekuji-uo" have been published up to now. As to the breeding season, Nakagawa (1897) stated as "the period of active egg-laying must be between the middle of June and the end of July" in Goshono-ura, while Oyama and Yoshii (1940) suggested that the spawning season may extend from the end of May to the middle of June in the northern part of Ariake Sea, and further according to Nogusa (1957) the season is May and June in Saizaki, Hiroshima Prefecture. Kumada (1936) reported that 2-5 individuals of "Namekuji-uo" were obtained, by every operation of a sampler which could grasp $\left(10 \mathrm{~cm}^{2}\right)$ of bottom surface, in the Seto Inland Sea off Yamaguchi Prefecture. This is the only quantitative record as to the population density of "Namekuji-uo" that ever populated rather densely in various localities in Japan as also seen in Table 1. Kikuchi (1977) revealed recently that the animal inhabits nearly exclusively in 
the sand of $\mathrm{Md} \phi=0.7-1.5$ and $\mathrm{So}=1.1-1.7$, by analysing the collection data at the depth of 10-50 m off Tsuyazaki in Fukuoka Prefecture, and in the Hiuchi-nada, the Seto Inland Sea and Tomioka Bay, Amakusa. The pelagic larvae of the Japanese lancelets were firstly described by Shojima (1974) (see p. 149).

In karyology: Nogusa (1957) recorded, on 'Branchiosioma belcheri' from Hiroshima, that the haploid chromosomes are 16, this number is larger than that previously known on $B$. lanceolatum (10-12, according to Makino, 1950, pp. 137-138). Recently, however, both of these two records are questioned by Colombera (1974).

In histology: Nakao (1964 and 1965) described the fine structure of the photoreceptor and the excretory organ of 'Branchiostoma belcheri' from the Japanese waters respectively, Kataoka and Fujita (1974) reported the occurrence of endocrine cells in the posterior part of the mid-gut in the specimens of 'Branchiostoma japonicum', and Anno and Kawai (1975) investigated the mucopolysaccharides of the connective tissue of 'Branchiostoma belcherii' from the Seto Inland Sea.

\section{Results of Morphological Observations}

The most important part of the morphological observations was occupied by the measurement of respective meristic characters, the results of which as given in Tables 2 and 3. In addution, the following notes seem necessary to make the status of Japanese "Namekuji-uo" clear.

1. In nearly all the specimens examined in the present study, inclusive of those from Amoy, the shape of the rostral and caudal fins and the relative position of the anus to the lower caudal fin are very similar; the post-rostral notch is more or less distinct, the caudal fin is rather remarkably distinguishable from the body and the anus is situated nearly at the center of the lower caudal fin.

2. The number of the dorsal and preanal fin-ray chambers seems clearly invariable with the body length, as already shown by Tchang-Si and Koo (1936, p. 83) on $B$. belcheri var. tsingtauense from Kiaochow Bay and by Boschung and Gunter (1962, p. 251) on B. caribaeum Sundevall from the Gulf of Mexico (for the number of the dorsal fin-ray chambers only). According to Webb (1957, p. 255), however, the preanal fin-ray chambers "increase with the age of the animal" in B. elongatum (Sundevall) from Peru. And seemingly no correlation is discernible between the number of the dorsal fin-ray chambers and that of the preanal ones in the specimens examined here.

3. The number of myotomes is also clearly invariable with the body length, as already shown by Nakagawa (see p. 142), and by Boring and Li (1932, p. 11) on $B$. belcheri from Amoy and by Tchang-Si and Koo (1936, p. 81) on B. belcheri var. tsingtauense.

4. The correlation between the number of buccal cirri and the body length may be seen in Figure 2. Although this figure is composed of the data on the specimens from different localities, it is clearly suggesting that the buccal cirri increase with growth. The statement of Nakagawa on this point was correct within a certain range of body 
Table 2. Meristic characters of $B$. belcheri from the Japanese waters. Character numbers 1-11 are: 1 , number of dorsal fin-ray chambers; 2 , that of preanal fin-ray chambers; 3 , ratio of height to breadth of dorsal fin-ray chambers; 4 , relative height of total body to dorsal fin; 5 , relative length of postatrial region to preatrial region; 6 , number of myotomes from anterior end to atriopore; 7, that from atriopore to anus; 8 , that posterior to anus; 9 , total number of myotomes; 10 , total body length $(\mathrm{mm}) ; 11$, number of examined specimens. Numerals in parentheses

\begin{tabular}{|c|c|c|c|c|c|c|}
\hline Locality (Number) & Material & 1 & 2 & 3 & 4 & 5 \\
\hline (2) Misaki & $\mathrm{K}$ & ca. 200 & $56,58,60$ & $3.3-4.4$ & $7.6-10.4$ & $0.43,0.45,0.49$ \\
\hline \multicolumn{7}{|l|}{ (2) Misaki } \\
\hline (3) Shimoda & $\mathbf{L}$ & 290 & 47 & 3.7 & 10.0 & 0.41 \\
\hline (4) Gamagori & A-1 & $\begin{array}{l}260-280 \\
274.4 \pm 8.82\end{array}$ & $\begin{array}{l}50-56 \\
51.2 \pm 2.68 \\
\end{array}$ & $1.8-2.8$ & $9.8-13.0$ & $\begin{array}{l}0.45-0.50 \\
0.48 \pm 0.02\end{array}$ \\
\hline (4) Gamagori & $\mathrm{D}$ & 310 & 64 & 2.5 & 二 & 0.49 \\
\hline (7) Tanabe Bay & Q & $260,280,300$ & $52,57,66^{*}$ & $3.5-5.0$ & $7.2-9.5$ & $0.44,0.45,0.47$ \\
\hline (8) Gobo & $\mathrm{T}$ & $\begin{array}{l}290-310 \\
298.3 \pm 8.37 \\
\end{array}$ & $\begin{array}{l}60-63 \\
61.4 \pm 1.34 \\
\end{array}$ & ca. 5 & $\ldots$ & $\begin{array}{l}0.43-0.49 \\
0.46 \pm 0.04 \\
\end{array}$ \\
\hline (10) Jino-oshima & $\mathrm{H}$ & 280 & 58 & 4.0 & 8.4 & 0.52 \\
\hline (11) Tanagawa & $\mathrm{D}$ & $\begin{array}{l}280-326(11) \\
294.5 \pm 15.3\end{array}$ & $\begin{array}{l}54-66(12) \\
59.0 \pm 4.36\end{array}$ & $3.5-6.0$ & $7.2-11.0$ & $\begin{array}{l}0.38-0.50(11) \\
0.46 \pm 0.04\end{array}$ \\
\hline (12) Sumoto & $B-1$ & $\begin{array}{l}280-350(18) \\
311.8 \pm 25.0 \\
\end{array}$ & $\begin{array}{l}54-66(17) \\
58.6 \pm 4.14 \\
\end{array}$ & $2.3-4.0$ & $8.3-11.5$ & $\begin{array}{l}0.42-0.51 \\
0.46 \pm 0.03\end{array}$ \\
\hline (13) Kobe & $\mathrm{M}$ & 300 & 64 & 3.9 & - & 0.46 \\
\hline (14) Maruyama & $\mathrm{G}-1$ & 320 & 59 & 4.5 & 10.5 & 0.46 \\
\hline (15) Fukura & $\mathrm{G}=3$ & 300 & 58 & 5.0 & 10.0 & 0.48 \\
\hline (16) Shikanose & $\mathrm{E}-3$ & $\begin{array}{l}270-320 \\
289.1 \pm 15.8 \\
\end{array}$ & $\begin{array}{l}54-66 \\
60.3 \pm 4.05 \\
\end{array}$ & $2.5-5.0$ & $8.2-12.0$ & $\begin{array}{l}0.44-0.50 \\
0.47 \pm 0.02\end{array}$ \\
\hline (17) Tomo & $\mathrm{B}-2$ & 260,305 & ca. 50 & $\longrightarrow$ & - & $0.45,0.52$ \\
\hline (18) Onomoichi & $F-1$ & 330 & 50 & 2.8 & 12.0 & 0.43 \\
\hline (18) Onomichi & $\mathrm{E}-2$ & 310 & 58 & 3.0 & 10.6 & 0.45 \\
\hline (19) Mihara & $\mathrm{N}$ & 330 & 56 & 4.0 & 7.0 & 0.40 \\
\hline (19) Mihara & $A-2$ & $\begin{array}{l}276-310 \\
290.6 \pm 10.5 \\
\end{array}$ & $\begin{array}{l}53-68 \\
60.7 \pm 4.59 \\
\end{array}$ & $2.3-4.5$ & $8.3-11.6$ & $\begin{array}{l}0.44-0.48 \\
0.46 \pm 0.02\end{array}$ \\
\hline (20) Hosojima & $\mathrm{R}$ & 270 & 55 & 3.5 & 10.4 & 0.52 \\
\hline (21) Nishiwaki & G-2 & 290 & 54 & 4.5 & 9.6 & 0.52 \\
\hline (23) Nyugawa & I & $280,300,320$ & $50,52,58$ & $3.0-3.8$ & $8.0-10.0$ & $0.44,0.45,0.47$ \\
\hline (29) Bungo Channel & A-3 & ca. $280(1)$ & $=$ & $=$ & - & $0.46,0.51,0.53$ \\
\hline (30) Usa & $\mathrm{O}$ & ca. 330 & 56 & 3.3 & 13.5 & 0.48 \\
\hline (31) Shimonoseki & & 270 & 59 & & & \\
\hline (33) Koga & $\mathrm{S}$ & $\begin{array}{l}270-300 \\
287.5 \pm 15.0\end{array}$ & $\begin{array}{l}4560 \\
53.8 \pm 6.75 \\
\end{array}$ & $2.8-4.0$ & $10.0-11.0$ & $\begin{array}{l}0.48-0.51 \\
0.49 \pm 0.02 \\
\end{array}$ \\
\hline \multicolumn{7}{|l|}{ (34) Shikanoshima } \\
\hline (35) Off Shikanoshima & $J$ & 280,300 & 50,56 & $5.5(1)$ & 9.0 & $0.45,0.53$ \\
\hline (36) Ariake & $\mathrm{C}-1$ & $\begin{array}{l}280-300(5) \\
290.0 \pm 7.07 \\
\end{array}$ & $\begin{array}{l}56-60(4) \\
57.5 \pm 1.91 \\
\end{array}$ & $2.2-5.0$ & $6.7-10.0$ & $\begin{array}{l}0.42-0.49 \\
0.46 \pm 0.03\end{array}$ \\
\hline (36) Ariake & A-4 & $\begin{array}{l}270310 \\
292.5 \pm 17.1 \\
\end{array}$ & $\begin{array}{l}48-55 \\
50.8 \pm 3.00 \\
\end{array}$ & $2.5-3.6$ & $10.0-12.5$ & $\begin{array}{l}0.45-0.48 \\
0.46 \pm 0.01 \\
\end{array}$ \\
\hline (36) Ariake & A-5 & ca. $300(1)$ & 50.60 & $1.8,3.0$ & 9.2 & $0.47,0.51$ \\
\hline (37) Shimabara & $\mathrm{F}$ & $\begin{array}{l}265-310 \\
285 \pm 16.4 \\
\end{array}$ & $\begin{array}{l}54-61 \\
55.6 \pm 2.12 \\
\end{array}$ & $2.6-4.4$ & $7.5-11.2$ & $\begin{array}{l}0.44-0.50 \\
0.46 \pm 0.02 \\
\end{array}$ \\
\hline \multicolumn{7}{|l|}{ (38) Goshiono-rua } \\
\hline (39) Amakusa & $B-3$ & 290,300 & 58,60 & $4.1,5.0$ & $6.1,9.0$ & $0.47,0.48$ \\
\hline
\end{tabular}


in each column of characters indicate the number of specimens that could be actually examined as to respective characters. * This is the corrected number of the preanal fin-ray chambers in Specimen A (Nishikawa 1978, Table 1), that were erroneously given as 74. ** Means and standard deviations were calculated by the present author on the measurements given in the original papers.

\begin{tabular}{|c|c|c|c|c|c|c|}
\hline 6 & 7 & 8 & 9 & 10 & 11 & Source \\
\hline 37,38 & 17,18 & 11 & $65,67,68$ & $42.3-52.5$ & 3 & by present study \\
\hline 37 & 16 & $10-11$ & $63-64$ & 45.5 & $?$ & Jordan \& Snyder, 1901 \\
\hline 38 & 19 & $10 ?$ & $67 ?$ & 31.8 & 1 & by present study \\
\hline $\begin{array}{l}37-38 \\
37.2 \pm 0.47\end{array}$ & $\begin{array}{l}16-17 \\
16.6 \pm 0.55\end{array}$ & $\begin{array}{l}10-11 \\
10.2 \pm 0.45\end{array}$ & 64 & $30.7-50.6$ & 5 & do. \\
\hline 37 & 17 & 10 & 64 & 48.2 & 1 & do. \\
\hline $39-40$ & $17-19$ & 9,11 & 67,69 & $29.7-39.8$ & 3 & do. \\
\hline 38 & $18(4)$ & $\begin{array}{l}10-11 \\
10.4 \pm 0.55\end{array}$ & $\begin{array}{l}66-67(4) \\
66.3 \pm 0.51 \\
\end{array}$ & $14.8-19.6$ & 5 & do. \\
\hline 38 & 17 & 11 & 66 & 24.7 & 1 & do. \\
\hline $\begin{array}{l}38-39(11) \\
38.8 \pm 0.41 \\
\end{array}$ & 17 & $\begin{array}{l}10-11(11) \\
10.9 \pm 0.30\end{array}$ & $\begin{array}{l}66-67(11) \\
66.7 \pm 0.47 \\
\end{array}$ & $10.8-30.5$ & 13 & do. \\
\hline $\begin{array}{l}37-41(18) \\
38.4+0.98 \\
\end{array}$ & $\begin{array}{l}16-18(18) \\
17.2 \pm 0.55 \\
\end{array}$ & $\begin{array}{l}9-12(18) \\
10.6 \pm 0.70\end{array}$ & $\begin{array}{l}64-69(18) \\
66.3 \pm 1.49 \\
\end{array}$ & $36.2-57.3$ & 19 & do. \\
\hline 39 & 17 & 12 & 68 & 16.0 & 1 & do. \\
\hline 39 & 17 & 10 & 66 & 35.0 & 1 & do. \\
\hline 38 & 17 & 11 & 66 & 14.1 & 1 & do. \\
\hline $\begin{array}{l}38-39 \\
38.6 \pm 0.51\end{array}$ & $\begin{array}{l}17-19 \\
17.5 \pm 0.69\end{array}$ & $\begin{array}{l}10-11 \\
10.9 \pm 0.30\end{array}$ & 67 & $29.7-39.8$ & 11 & do. \\
\hline - & - & 一 & - & - & 2 & do. \\
\hline 41 & 16 & 9 & 66 & 54.5 & 1 & do. \\
\hline 38 & 17 & 10 & 65 & 52.5 & 1 & do. \\
\hline 39 & 17 & 11 & 67 & 39.0 & 1 & do. \\
\hline $\begin{array}{l}37-39 \\
38.2 \pm 0.42\end{array}$ & $\begin{array}{l}17-18 \\
17.4 \pm 0.52\end{array}$ & $\begin{array}{l}10-11 \\
10.9 \pm 0.32\end{array}$ & $\begin{array}{l}66-67 \\
66.5 \pm 0.53 \\
\end{array}$ & $24.7-56.4$ & 10 & do. \\
\hline 38 & 18 & 9 & 65 & 43.1 & 1 & do. \\
\hline 38 & 18 & 10 & 66 & 25.8 & 1 & do. \\
\hline 39 & 17 & 11 & 67 & $44.0-49.1$ & 3 & do. \\
\hline 38,39 & 17 & $9,10,11 ?$ & 65,66 & $14.7-27.6$ & 3 & do. \\
\hline 38 & 18 & 10 & 66 & 37.0 & 1 & do. \\
\hline 39 & 17 & 9 & 65 & 10.0 & 1 & Franz, 1922 \\
\hline $\begin{array}{l}37-38 \\
37.6 \pm 0.55\end{array}$ & 17 & $\begin{array}{l}10-11 \\
10.5 \pm 0.58\end{array}$ & 65 & $31.7-43.8$ & 4 & by present study \\
\hline 37 & 16 & 11 & 64 & $29.5-46$ & 6 & Andrews, 1895 \\
\hline 38,39 & 17 & 11 & 66,67 & $13.6,19.3$ & 2 & by present stydy \\
\hline $\begin{array}{l}36-37 \\
36.8 \pm 0.41\end{array}$ & 17 & $\begin{array}{l}10-11 \\
10.5 \pm 0.55\end{array}$ & $\begin{array}{l}63-65 \\
64.3 \pm 0.82 \\
\end{array}$ & $27.5-40.7$ & 6 & do. \\
\hline $\begin{array}{l}37-39 \\
37.8 \pm 0.96\end{array}$ & $\begin{array}{l}16-17 \\
16.8 \pm 0.50\end{array}$ & $\begin{array}{l}10-11 \\
10.8 \pm 0.50\end{array}$ & $\begin{array}{l}64-67 \\
65.3 \pm 1.26\end{array}$ & $38.3-47.5$ & 4 & do. \\
\hline 37,38 & 16,17 & $9 ?, 11$ & 64 & $39.5,42.6$ & 2 & do. \\
\hline $\begin{array}{l}36-38 \\
36.9 \pm 0.57\end{array}$ & $\begin{array}{l}17-18 \\
17.1 \pm 0.32 \\
\end{array}$ & $\begin{array}{l}10-11 \\
10.6 \pm 0.52\end{array}$ & $\begin{array}{l}64-65 \\
64.6 \pm 0.52 \\
\end{array}$ & $29.0-46.6$ & 10 & do. \\
\hline $\begin{array}{l}35-38 \\
36.5 \pm 0.68\end{array}$ & $\begin{array}{l}16-18 \\
17.0 \pm 0.49\end{array}$ & $\begin{array}{l}9-12 \\
10.6 \pm 0.58\end{array}$ & $\begin{array}{l}62-66 \\
64.1 \pm 0.74\end{array}$ & $10.5-54.0$ & 58 & Nakagawa, 1897** \\
\hline 36,38 & 17 & 10 & 63,65 & $37.5,46.5$ & 2 & by present study \\
\hline
\end{tabular}


Table 3. Meristic characters of B. belcheri and B. belcheri var. tsingtauense (***) from foreign

\begin{tabular}{|c|c|c|c|c|c|}
\hline Locality (Material) & 1 & 2 & 3 & 4 & 5 \\
\hline Kiaochow Bay*** & $\begin{array}{l}284-363(25) \\
320.8 \pm 17.5\end{array}$ & $\begin{array}{l}51-73(20) \\
60.6 \pm 4.90\end{array}$ & & & \\
\hline Amoy (A-6) & $\begin{array}{l}300-330 \\
313.8 \pm 13.4\end{array}$ & $\begin{array}{l}68-91 \\
80.6 \pm 6.40\end{array}$ & $2.0-3.5$ & $9.5-13.0$ & $\begin{array}{l}0.44-0.50 \\
0.46 \pm 0.02\end{array}$ \\
\hline Amoy? (A-7) & $\begin{array}{l}290-340 \\
311.1 \pm 13.6\end{array}$ & $\begin{array}{l}65-90 \\
80.8 \pm 6.92\end{array}$ & $2.0-3.6$ & $9.5-16.0$ & $\begin{array}{l}0.43-0.53 \\
0.50 \pm 0.03\end{array}$ \\
\hline Amoy? (A-8) & $\begin{array}{l}300-330(24) \\
312.5 \pm 11.1\end{array}$ & $\begin{array}{l}70-92(27) \\
79.3 \pm 5.60\end{array}$ & $2.0-3.2$ & $9.5-12.0$ & $\begin{array}{l}0.39-0.54 \\
0.49 \pm 0.03\end{array}$ \\
\hline Amoy (B-4) & $\begin{array}{l}320-340 \\
330.0 \pm 10.0\end{array}$ & $\begin{array}{l}80-87 \\
82.6 \pm 2.97\end{array}$ & $2.6-3.0$ & $10.0-14.0$ & $\begin{array}{l}0.46-0.50 \\
0.47 \pm 0.02\end{array}$ \\
\hline Amoy (C-2) & $\begin{array}{l}300-320 \\
312.0 \pm 11.0\end{array}$ & $\begin{array}{l}76-90 \\
83.6 \pm 5.55\end{array}$ & $2.7-4.0$ & $11.0-15.0$ & $\begin{array}{l}0.42-0.48 \\
0.46 \pm 0.03\end{array}$ \\
\hline \multicolumn{6}{|l|}{ Amoy } \\
\hline Amoy & $\begin{array}{l}305-338(14) \\
321.2 \pm 11.5\end{array}$ & $\begin{array}{l}76-94(40) \\
83.4 \pm 4.90\end{array}$ & & & \\
\hline Amoy & $\begin{array}{l}262-393 ? \\
313\end{array}$ & $\begin{array}{l}35-90 \\
72\end{array}$ & & & \\
\hline Amoy & $\begin{array}{l}250-340 \\
305 \pm 23.64\end{array}$ & $\begin{array}{l}67-90 \\
78.1 \pm 5.26\end{array}$ & $\begin{array}{l}2.5-3.5 \\
2.96 \pm 0.31\end{array}$ & $\begin{array}{l}7-11 \\
9.08 \pm 0.96\end{array}$ & $\begin{array}{l}0.42-0.54 \\
0.50 \pm 0.024\end{array}$ \\
\hline \multicolumn{6}{|l|}{$\begin{array}{l}\text { Prince of Wales Island, } \\
\text { Torres Strait }\end{array}$} \\
\hline \multicolumn{6}{|l|}{ Borneo (type locality) } \\
\hline Bedok, Singapore & 340 & 90 & 3.0 & 9.0 & 0.47 \\
\hline \multicolumn{6}{|l|}{$\begin{array}{l}\text { Mergui Archipelago, } \\
\text { Andaman Sea }\end{array}$} \\
\hline \multicolumn{6}{|l|}{ Ceylon } \\
\hline \multicolumn{6}{|l|}{ Ceylon } \\
\hline \multicolumn{6}{|l|}{ Tuticorin, India } \\
\hline \multicolumn{6}{|l|}{ Off Coilpaton, India } \\
\hline \multicolumn{6}{|l|}{ Tholayiran par, India } \\
\hline Bagamoya, Tanzania & 275 & ca. 70 & & & \\
\hline $\begin{array}{l}\text { Nosy-bé, N.W. coast of } \\
\text { Madagascar }\end{array}$ & 280 & 65 & $3-4$ & 8 & 0.4 \\
\hline $\begin{array}{l}\text { Linga-linaga, } \\
\text { Mosambique }\end{array}$ & $\begin{array}{l}258-306 \\
287.0 \pm 15.5\end{array}$ & $\begin{array}{l}70-88 \\
80.6 \pm 5.61\end{array}$ & $\begin{array}{l}3.0-3.6 \\
3.17+0.24\end{array}$ & $\begin{array}{l}7-10 \\
8.8 \pm 0.97\end{array}$ & $\begin{array}{l}0.43-0.47 \\
0.45 \pm 0.012\end{array}$ \\
\hline $\begin{array}{l}\text { Off Mosambique Is., } \\
\text { Mosambique }\end{array}$ & 276 & 68 & 4.0 & 8 & 0.46 \\
\hline
\end{tabular}

length (see p. 142). It may be, however, rather natural that the correlation pattern varies somewhat according to different localities. The increase of the buccal cirri with growth has been also demonstrated by Boring and $\mathrm{Li}(1932, \mathrm{p} .14)$ on $B$. belcheri from Amoy, by Tchang-Si and $\mathrm{Koo}(1936$, p. 81) on B. belcheri var. tsingtauense from Kiaochow Bay and by Boschung and Gunter (1962, p. 253 and Fig. 20) on $B$. caribaeum Sundevall from the Gulf of Mexico. The conical papillae on the cirrus are almost always discernible, though the degree of their development is irregular; this is partly attributable to the epidermal deterioration in preservation.

5. The wheel organ consists usually of four rods on each side, though the number 
localities. For signs, see Table 2.

\begin{tabular}{|c|c|c|c|c|c|c|}
\hline 6 & 7 & 8 & 9 & 10 & 11 & Source \\
\hline $\begin{array}{l}37-40(150) \\
38.8 \pm 0.46\end{array}$ & $\begin{array}{l}16-18(160) \\
17.7 \pm 0.50\end{array}$ & $\begin{array}{l}10-12(150) \\
10.6 \pm 0.54\end{array}$ & $\begin{array}{l}65-69(150) \\
67.1 \pm 0.67\end{array}$ & -55 & & $\begin{array}{c}\text { Tcahng-Si \& Koo, } \\
1936 * *\end{array}$ \\
\hline $\begin{array}{l}36-38 \\
36.9+0.52\end{array}$ & $\begin{array}{l}16-18 \\
17.2+0.56\end{array}$ & $\begin{array}{l}10-11 \\
10.7 \pm 0.49\end{array}$ & $\begin{array}{l}64-66 \\
64.7 \pm 0.59\end{array}$ & $36.2-45.4$ & 15 & by present study \\
\hline $\begin{array}{l}36-38 \\
36.9 \pm 0.40\end{array}$ & $\begin{array}{l}17-18 \\
17.4 \pm 0.49\end{array}$ & $\begin{array}{l}10-11 \\
10.3 \pm 0.48\end{array}$ & $\begin{array}{l}64-66 \\
64.6 \pm 0.72\end{array}$ & $28.0-43.4$ & 30 & do. \\
\hline $\begin{array}{l}36-38(29) \\
37.0 \pm 0.33\end{array}$ & $\begin{array}{l}17-18(28) \\
17.3 \pm 0.46\end{array}$ & $\begin{array}{l}10-11(28) \\
10.8 \pm 0.39\end{array}$ & $\begin{array}{l}64-66(28) \\
65.1 \pm 0.53\end{array}$ & $22.5-43.7$ & 30 & do. \\
\hline $\begin{array}{l}35-36 \\
35.8 \pm 0.48\end{array}$ & $\begin{array}{l}16-17 \\
16.6 \pm 0.55\end{array}$ & $\begin{array}{l}9.11 \\
10.0 \pm 0.71\end{array}$ & $\begin{array}{l}63-64 \\
63.4 \pm 0.55\end{array}$ & $34.5-40.3$ & 5 & do. \\
\hline $\begin{array}{l}36-37 \\
36.4 \pm 0.55\end{array}$ & $\begin{array}{l}17-18 \\
17.4 \pm 0.55\end{array}$ & $\begin{array}{l}10-11 \\
10.8 \pm 0.45\end{array}$ & $\begin{array}{l}64-65 \\
64.6 \pm 0.55\end{array}$ & $37.8-41.3$ & 5 & do. \\
\hline $\begin{array}{l}36-37 \\
36.8+0.44\end{array}$ & $\begin{array}{l}16-18 \\
17.1+0.44\end{array}$ & $\begin{array}{l}9-11 \\
10.2+0.44\end{array}$ & $\begin{array}{l}63-65 \\
64.0+0.22\end{array}$ & $35.5-47.0$ & 41 & Boring \& Li, 1932** \\
\hline $\begin{array}{l}34-38(112) \\
36.4 \pm 0.64\end{array}$ & $\begin{array}{l}16-19(112) \\
17.3 \pm 0.58\end{array}$ & $\begin{array}{l}10-12(112) \\
10.9 \pm 0.52\end{array}$ & $\begin{array}{l}62-66(112) \\
64.7 \pm 0.74\end{array}$ & -48 & & $\begin{array}{c}\text { Tchang-Si \& Koo, } \\
\text { 1936** }\end{array}$ \\
\hline $\begin{array}{l}36-39 \\
38\end{array}$ & $\begin{array}{l}16-18 \\
17\end{array}$ & $\begin{array}{l}9-11 \\
10\end{array}$ & $\begin{array}{l}63-65 \\
64\end{array}$ & -57 & $?$ & Chin, 1941 \\
\hline $\begin{array}{l}35-38 \\
36.5 \pm 0.82\end{array}$ & $\begin{array}{l}15-18 \\
17.0 \pm 0.76\end{array}$ & $\begin{array}{l}9-11 \\
10.0 \pm 0.54\end{array}$ & $\begin{array}{l}62-65 \\
63.56 \pm 1.0\end{array}$ & $20-46$ & 25 & Webb, $1956 c$ \\
\hline $37-38$ & $16-17$ & 10 & 63,65 & & 4 & Kirkaldy, 1895 \\
\hline 37 & 14 & 13 & 64 & & 1 & $\begin{array}{l}\text { Gunther, } 1884 \text { (cited } \\
\text { from Tattersall, 1903) }\end{array}$ \\
\hline 37 & 19 & 10 & 66 & 44 & 1 & Webb, 1956a \\
\hline $37-38$ & $17-18$ & $9-10$ & & -52 & 11 & Prashad, 1934 \\
\hline $\begin{array}{l}36-39 \\
37.9 \pm 0.73\end{array}$ & $\begin{array}{l}16-18 \\
17.1 \pm 0.42\end{array}$ & $\begin{array}{l}8-10 \\
8.95 \pm 0.48\end{array}$ & $\begin{array}{l}63-66 \\
63.9 \pm 0.70\end{array}$ & $26-56$ & 55 & Tattersall, $1903^{* *}$ \\
\hline $\begin{array}{l}37-38 \\
37.4+0.58\end{array}$ & $\begin{array}{l}16-18 \\
17.0+0.71\end{array}$ & $\begin{array}{l}9-10 \\
9.40+0.55\end{array}$ & $\begin{array}{l}63-65 \\
63.8 \pm 0.84\end{array}$ & $47-56$ & 5 & Franz, 1922** \\
\hline $\begin{array}{l}37-38 \\
37.3 \pm 0.73\end{array}$ & $\begin{array}{l}17-19 \\
17.4 \pm 0.84\end{array}$ & $\begin{array}{l}9-10(7) \\
9.43 \pm 0.54\end{array}$ & $\begin{array}{l}63-66(7) \\
64.3 \pm 1.00\end{array}$ & $27-47$ & 9 & Franz, $1922 * *$ \\
\hline 37 & 17 & 10 & 64 & $20-45$ & $?$ & Prashad, 1934 \\
\hline 37 & 17 & $9-10$ & $63-64$ & $30-35$ & 4 & do. \\
\hline 38 & 16 & 9 & 63 & 26 & 1 & Franz, 1922 \\
\hline 37 & 17 & $9-10$ & $63-64$ & $43-52$ & 4 & Massé, 1964 \\
\hline $\begin{array}{l}36-39 \\
37.1 \pm 0.79\end{array}$ & $\begin{array}{l}17-19 \\
17.7 \pm 0.71\end{array}$ & $\begin{array}{l}9-11 \\
9.9 \pm 0.60\end{array}$ & $\begin{array}{l}63-66 \\
64.7 \pm 1.12\end{array}$ & $42-48$ & 9 & Webb, 1957 \\
\hline 34 & 17 & 11 & 62 & 62 & 1 & do. \\
\hline
\end{tabular}

and shape of rods may vary slightly. This structure cannot be always observed, probably partly for some artificial causes.

6. Figure 3 shows the relation between the number of gonads on each side and the body length, basing on the two lots of specimens from Japan and the same number of lots from Amoy. These four lots were selected, because the specimens in them seemed to hold the complete series of gonads on each side; the gonads are usually found partly injured or lost in many specimens. This figure seems to suggest the following points:

a. Any correlation is hardly discernible between the number of gonads and 
the body length so far as this figure is concerned.

b. In each specimen, the number of gonads may, if not all, be larger on the right side than on the left by 1 to 3 ; the same trend may also be seen in the

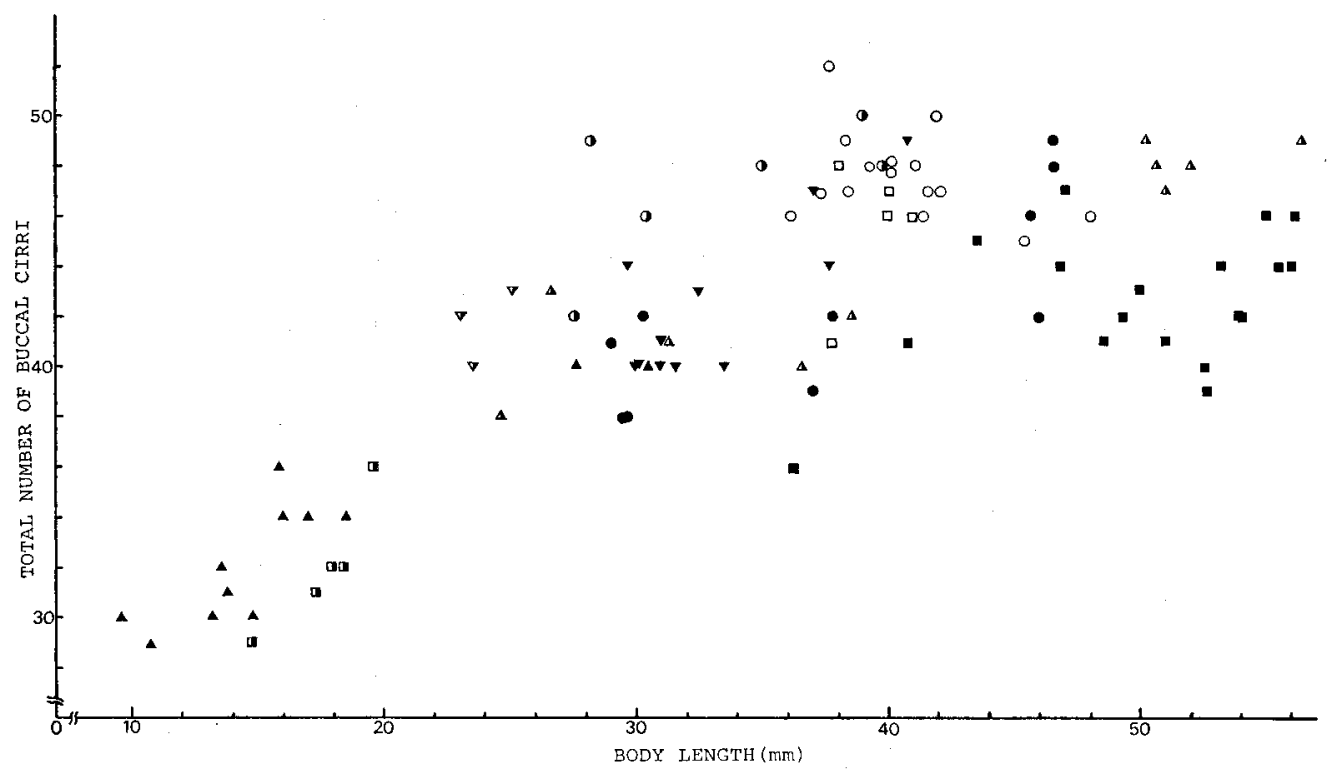

Fig. 2. Correlation between the total number of buccal cirri and the body length in the specimen lots of $B$. belcheri from Tanagawa (Material D: solid triangle), Shikanose (E-3: inverted solid triangle), Sumoto (B-1: solid square), Gobo (T: semi-open square), Tanabe Bay (Q: inverted semi-open triangle), Mihara (A-2: semi-open triangle), Shimabara (F: solid circle), Ariake (C-1: semi-open circle), and Amoy (A-6: open circle and C-2: open square).

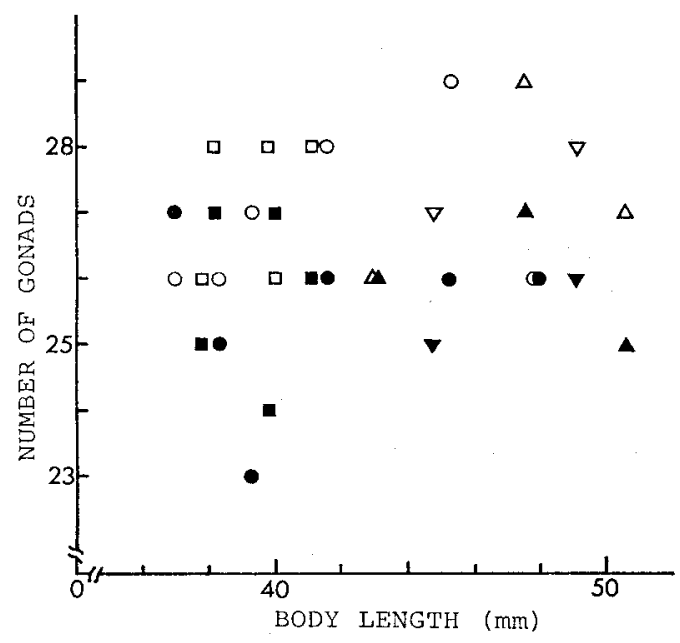

Fig. 3. Relation between the number of gonads and the body length. The number of gonads seemingly in complete series is plotted here, basing on the specimen lots from Gamagori (Material A-1: triangle), Ehime (I: inverted triangle) and Amoy (circle for A-6 and square for C-2). Solid for the number of gonads on the left side and open for that on the right. 
specimens of $B$. belcheri from Amoy (Chin, 1941, p. 373 and Tchang-Si and Koo, 1936, p. 86) and India (Prashad, 1934), and in B. belcheri var. tsingtauense from Kiaochow Bay (Tchang-Si and Koo, 1936, pp. 82 and 86). The number of gonads itself may be rather constant throughout the whole specimens examined in the present study.

7. The smallest individual with seemingly matured gonads in the present material is a $27.6 \mathrm{~mm}$ long specimen from Bungo Channel, this is lightly smaller than the 29 mm long specimen "with full-grown gonads" from Amoy (Chin, 1941, p. 372), but larger than the $25 \mathrm{~mm}$ long one with "full-sized gonads" from Amakusa (Nakagawa 1897, p. 127).

From what are seen in Table 2 and the above-mentioned additional features, it seems that no significant differences exist among the examined specimens from the Japanese waters, except in the total number of myotomes. In this character, the specimens from Ariake, Shimabara and Amakusa may possibly be distinguished from those from other localities except Gamagori (Locality No. 4). Roughly speaking, total myotomes are 64-65 on an average in the specimens from Ariake, Shimabara and Amakusa, while 66-67 in the specimens from the other Japanese localities. In this respect, the specimens from Amakusa treated in the present study are seemingly corresponding to those previously measured by Nakagawa (1897). On the other hand, the measurements of the specimens from Misaki and from around Shikanoshima in the present study clearly do not agree with the previous measurements given by Jordan and Snyder (1901) and Andrews (1895) on the specimens from the same locality. This makes the problem very confused and seemingly makes the above-mentioned difference in the number of total myotomes insignificant. The number of myotomes or other segmental structures may be more or less influenced by water temperature in some stages during the development as seen in the variation in the number of vartebrae in some teleosts that was demonstrated by Hubbs (1922b, 1924, 1926 et al.) and many others (see, for example, Fowler, 1970; Ali and Lindsey, 1974). The number of myotomes might possibly fluctuate with the water temperature, and thus naturally according to different localities and even from year to year at the same locality. Further crucial analyses of this problem must be retained for future studies. As to this problem, refer also the suggestion of Wickstead on the possibility of increase of myotomes in pelagic larvae (see p. 152).

The specimens from Amoy examined in the present study are similar, in nearly all the characters checked, to those of $B$. belcheri previously recorded as seen in Table 3 .

\section{Pelagic Larvae}

Fifteen pelagic larvae of lancelets were found in the plankton samples collected during the plankton survey made by the Seikai Regional Fisheries Laboratory mainly around Kyusyu; all the samples were obtained by towing in the surface 0$164 \mathrm{~m}$ layer above the floor 112 to $2,080 \mathrm{~m}$ deep (Shojima 1974, table 1). These 
Table 4. Collection data after Shojima (1974) and meristic characters of "giant larvae" from the Japanese waters. The meristic characters are: 1, number of dorsal fin-ray chambers; 2, number of myotomes from the anterior end to anus; 3 , number of myotomes posterior to anus; 4 , total number of myotomes; 5 , body length $(\mathrm{mm}) ; 6$, number of gill slits.

\begin{tabular}{|c|c|c|c|c|c|c|c|c|c|c|c|}
\hline \multirow{2}{*}{$\begin{array}{l}\text { Specimen } \\
\text { Number }\end{array}$} & \multirow{2}{*}{$\begin{array}{c}\text { Site of } \\
\text { occurrence }\end{array}$} & \multirow{2}{*}{ Date } & \multirow{2}{*}{ Depth } & \multirow{2}{*}{$\begin{array}{l}\text { Layers } \\
\text { towed }\end{array}$} & \multirow{2}{*}{$\begin{array}{l}\text { Surface } \\
\text { Temp. }\end{array}$} & \multicolumn{6}{|c|}{ meristic characters } \\
\hline & & & & & & 1 & 2 & 3 & 4 & 5 & 6 \\
\hline 1 & $\begin{array}{l}36^{\circ} 21.5^{\prime} \mathrm{N} \\
131^{\circ} 14.0^{\prime} \mathrm{E}\end{array}$ & $\begin{array}{l}\text { Nov. } 21, ' 72 \\
\quad 1724-1734\end{array}$ & $>1,000$ & 0 & $17.2^{\circ} \mathrm{C}$ & 180 & 53 & 13 & 66 & $7.4 \mathrm{c}$ & a. 30 \\
\hline 2 & $\begin{array}{l}35^{\circ} 01.5^{\prime} \mathrm{N} \\
129^{\circ} 31.5^{\prime} \mathrm{E}\end{array}$ & $\begin{array}{l}\text { Oct. } 27, ' 73 \\
\quad 0750\end{array}$ & $<200$ & $0-72$ & 20.9 & 300 & 58 & 13 & 71 & 8.2 & 30 \\
\hline 3 & $\begin{array}{l}34^{\circ} 23.0^{\prime} \mathrm{N} \\
130^{\circ} 00.0^{\prime} \mathrm{E}\end{array}$ & $\begin{array}{l}\text { Nov. } 10, ' 73 \\
0848\end{array}$ & 113 & $0-110$ & 21.0 & 200 & 56 & $16 ?$ & $72 ?$ & 7.0 & 26 \\
\hline 4 & $\begin{array}{l}34^{\circ} 39.5^{\prime} \mathrm{N} \\
129^{\circ} 07.5^{\prime} \mathrm{E}\end{array}$ & $\begin{array}{l}\text { Oct. } 27, ' 73 \\
0230\end{array}$ & $<200$ & $0-137$ & 20.7 & 260 & 68 & 12 & 80 & 8.3 & - \\
\hline 5 & $\begin{array}{l}33^{\circ} 50.4^{\prime} \mathrm{N} \\
129^{\circ} 03.6^{\prime} \mathrm{E}\end{array}$ & $\begin{array}{l}\text { Nov. } 8,{ }^{\prime} 72 \\
2050\end{array}$ & 112 & $0-112$ & 22.2 & $200 ?$ & 56 & 12 & 68 & 6.9 & - \\
\hline 6 & $\begin{array}{l}33^{\circ} 42.5^{\prime} \mathrm{N} \\
129^{\circ} 10.0^{\prime} \mathrm{E}\end{array}$ & $\begin{array}{l}\text { Nov. } 8, ' 72 \\
2216\end{array}$ & 123 & $0-123$ & 22.1 & 310 & 56 & 11 & 67 & 7.0 & 29 \\
\hline 7 & $\begin{array}{l}32^{\circ} 18.5^{\prime} \mathrm{N} \\
128^{\circ} 29.0^{\prime} \mathrm{E}\end{array}$ & $\begin{array}{l}\text { May } 25,72 \\
0434\end{array}$ & 350 & $0-135$ & 20.0 & 100 & 56 & 11 & 67 & 6.6 & - \\
\hline 8 & $\begin{array}{l}32^{\circ} 05.9^{\prime} \mathrm{N} \\
128^{\circ} 45.0^{\prime} \mathbf{E}\end{array}$ & $\begin{array}{l}\text { Feb. } 17, ' 73 \\
0124\end{array}$ & 330 & $0-79$ & 18.5 & 336 & 58 & 11 & 69 & 8.2 & $25 ?$ \\
\hline 9 & $\begin{array}{l}31^{\circ} 38.4^{\prime} \mathrm{N} \\
130^{\circ} 00.1^{\prime} \mathrm{E}\end{array}$ & $\begin{array}{l}\text { Feb. 11, '70 } \\
\quad 0051-0112\end{array}$ & 163 & 0 & 18.7 & 256 & 54 & 13 & 67 & 7.0 & $25 ?$ \\
\hline 10 & $\begin{array}{l}31^{\circ} 30.7^{\prime} \mathrm{N} \\
128^{\circ} 29.1^{\prime} \mathrm{E}\end{array}$ & $\begin{array}{c}\text { Mar. 6, '74 } \\
1323-1334\end{array}$ & 520 & $0-46$ & 18.6 & $200 ?$ & $56 ?$ & $11 ?$ & $67 ?$ & 7.3 & $26 ?$ \\
\hline 11 & $\begin{array}{l}31^{\circ} 29.8^{\prime} \mathrm{N} \\
128^{\circ} 29.8^{\prime} \mathrm{E}\end{array}$ & $\begin{array}{r}\text { Nov. 24, '69 } \\
0750-0800\end{array}$ & 560 & 0 & 22.2 & 320 & 55 & 13 & 68 & 8.2 & 28 \\
\hline 12 & $\begin{array}{l}31^{\circ} 12.8^{\prime} \mathrm{N} \\
128^{\circ} 51.3^{\prime} \mathrm{E}\end{array}$ & $\begin{array}{l}\text { Mar. 6. '74 } \\
1916\end{array}$ & 690 & $0-117$ & 17.3 & 200 & 50 & 16 & 66 & 7.2 & 25 \\
\hline 13 & $\begin{array}{l}30^{\circ} 54.0^{\prime} \mathrm{N} \\
129^{\circ} 09^{\prime} 5^{\prime} \mathrm{E}\end{array}$ & $\begin{array}{r}\text { Feb. 11, } 69 \\
0305-0339\end{array}$ & 790 & $0-43$ & 17.2 & $150 ?$ & 49 & 13 & 62 & 6.5 & $25 ?$ \\
\hline 14 & $\begin{array}{l}30^{\circ} 51.6^{\prime} \mathrm{N} \\
130^{\circ} 28.0^{\prime} \mathrm{E}\end{array}$ & $\underset{1900}{\operatorname{Mar}, 1, ' 69}$ & 260 & $0-147$ & 17.2 & 170 & 53 & 13 & 66 & 7.0 & - \\
\hline 15 & $\begin{array}{l}25^{\circ} 49.5^{\prime} \mathrm{N} \\
125^{\circ} 19.2^{\prime} \mathrm{E}\end{array}$ & $\begin{array}{l}\text { Dec. } 10, ' 67 \\
0640\end{array}$ & 2,080 & $0-164$ & 23.1 & 300 & 67 & 17 & 84 & 10.3 & $24 ?$ \\
\hline
\end{tabular}

larvae that were once examined by Shojima (1974), were offered by his courtesy to the present author for further microscopical re-examination. The meristic characters thus cleared are given in Table 4.

The larvae are 6.5 to $10.3 \mathrm{~mm}$ long and with 25 to 30 gill slits. Comparing their body length and the number of gill slits with those of the previously described larvae of B. belcheri, B. belcheri var. tsingtauense and other species (see Lou, 1936, Bone, 1957, Wickstead and Bone, 1959 and Wickstead, 1975), these larvae may safely be defined as the "giant larva" that was ever named "Amphioxides" (for this, see 
Wickstead, 1964 and 1975). Their morphological features are as follows:

Mouth on the left side and without any cirri; dorsal fin only in the posterior part of body; caudal fin fan-shaped as previously described; dorsal fin-ray chambers, in many specimens, discernible only in the posterior part of body; preanal fin-ray chambers nearly indiscernible in the majority, though a few ones barely discerned in the specimens Nos. 2, 6 and 15.

Figure 4 shows the correlation between the total number of myotomes and the body length, while figure 5 shows the relation between the number of gill slits and

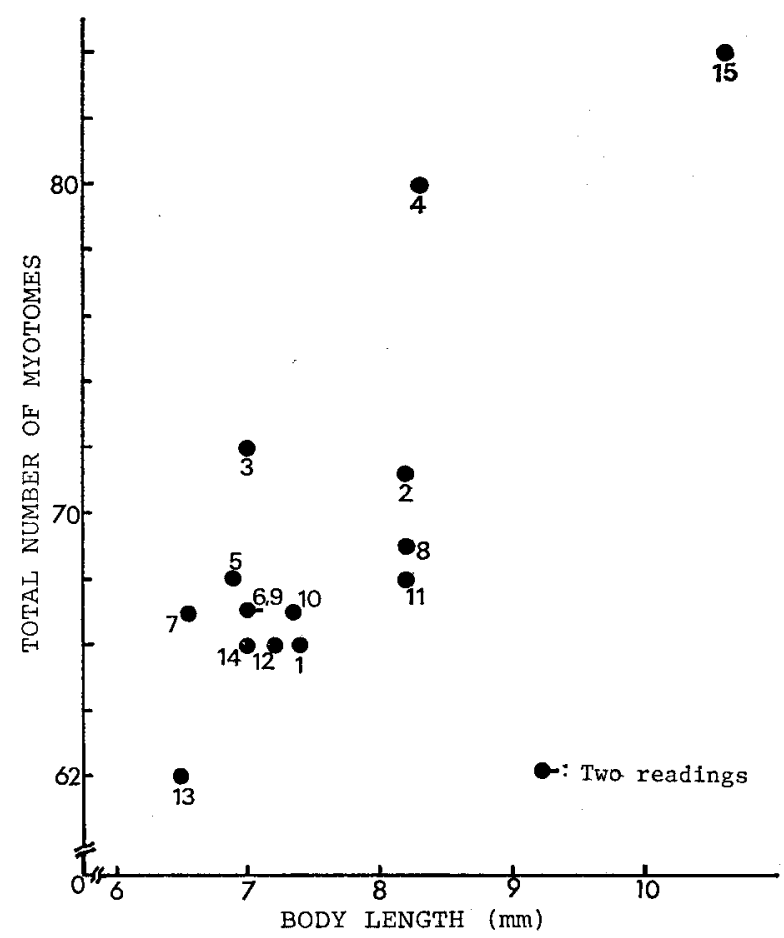

Fig. 4. Correlation between the total number of myotomes and the body length in "giant larvae". For specimen numbers, see Table 4.

the body length. The latter includes not only the measurements obtained in the present study but also those on the larvae of $B$. belcheri from Singapore (Wickstead and Bone, 1959) and the larvae of $B$. belcheri var. tsingtauense from Cheefou (=Tchéfou), Pohai Sea, China, that were provided with 56 preanal myotomes (Lou, 1936). Figure 5 suggests clearly some inter-specific trend in the correlation concerned, that is shown by Wickstead (1964, fig. 1 on p. 202). Of the examined larvac, those with 62 to 69 myotomes may probably be referrable to the "giant larvae" of $B$. belcheri (or var. tsingtauense). It is not impossible, however, that these larvae are assignable to "Amphioxides pelagicus", the accepted "giant larvae" of Asymmetron lucayanum with 58 to 71 myotomes, though the former are distinguishable from the latter only by their dorsal fin-ray chambers generally poorly developled. Wickstead 


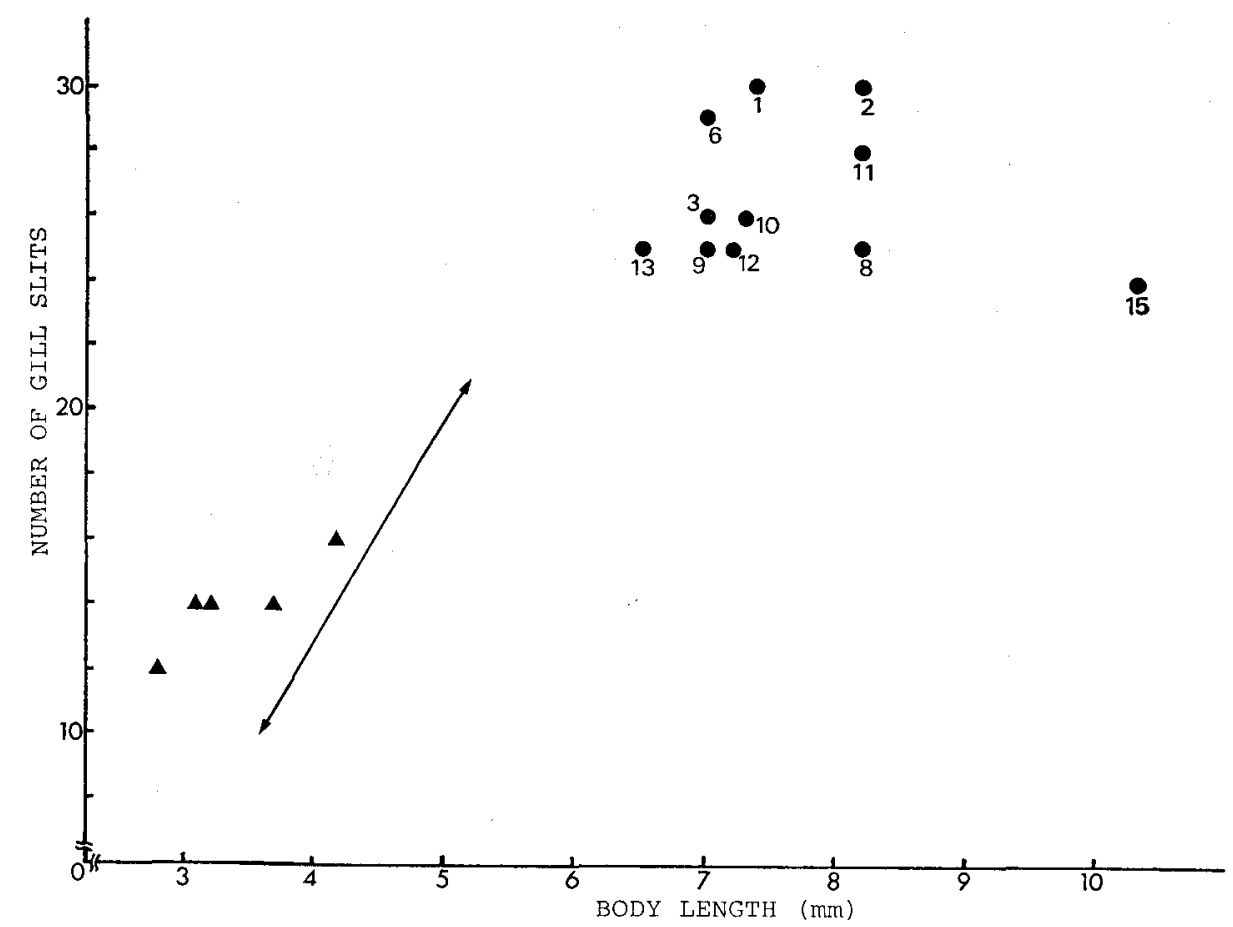

Fig. 5. Relationn between the number of gill slits and the body length, based on the measurements of the larvae examined in the present study (soild circle) and the measurements previously given by Lou (1936) on the larvac of $B$. belcheri var. tsingtauense from Cheefou (solid triangle) and by Wickstead and Bone (1959) on the larvae of B. belcheri from Singapore (indicated by an arrow showing only the range of the two variates).

(1964) suggested that "adults developed from giant larvae will differ slightly from adults developed from small larvae due to the development in the giant larvae of adaptations for a prolonged pelagic existence, e. g. a slight increase in the post-anal myotome number" (p. 206). If the myotomes increase to a certain extent in the pelagic life beyond the last stage of the "normal" development, the specimens with 71 and 72 myotomes found in the present larvae might also be assignable to $B . b e l$ cheri or some other species. Further, according to the number of myotomes, these larvae might be assignable to $A$. maldivense with $69-75$ myotomes, and the specimens with 80 and 84 myotomes in the present larvae to $A$. hectori ever recorded only from New Zealand and with 84-85 myotomes. Anyhow, it is urged to collect much more pelagic larvae, normal or giant, in the Western North Pacific in order to make it possible to identify the pelagic larvae exactly.

\section{Parasite}

A nematod was found strongly coiling between the right series of myotomes and the pharynx of the $19.3 \mathrm{~mm}$ long specimen from off Shikanoshima, $50 \mathrm{~m}$ deep; this is seemingly the first record of the nematod parasitic to the lancelets. 


\section{Taxonomic Status of "Namekuji-uo"}

All the features mentioned above or given in Tables 2 and 3, may be summarized taxonomically in the following three points:

1) In the number of total myotomes, the specimens of "Namekuji-uo" from Ariake, Shimabara and Amakusa on the west coast of Kyusyu Island are related very closely to the previously described typical form of $B$. belcheri, while most of the specimens from the localities in the Japanese waters other than Ariake, Shimabara Amakusa are very similar to $B$. belcheri var. tsingtauense.

2) In the number of preanal fin-ray chambers, all the specimens from the Japanese waters resemble closely $B$. belcheri var. tsingtauense.

3) In the other characters, the specimens examined in the present study are, in general, similar to the previously described specimens of both $B$. belcheri and its var. tsingtauense.

Then, the following conclusion may safely be deducible that "Namekuji-uo" in the Japanese waters except those from Ariake, Shimabara and Amakusa on the west coast of Kyusyu Island may be identified with $B$. belcheri var. tsingtauense recorded from Kiachow Bay, North China, while those inhabiting along the coasts of Ariake, Shimabara and Amakusa are seemingly reprsenting an intermediate form between this variety and the stem form of the species. Although the decisive taxonomic status of such "intermediate" forms is still pending, it is very possible that var. tsingtauense may be definable but inseparable distinctly from the type form of $B$. belcheri. Under these circumstances, "Namakuji-uo" may be referred, at present, to B. belcheri (Gray, 1847); nakagawae and japonicum being treated as the synonyms of belcheri.

Of the twelve species of Branchiostoma recorded from the Indo-Pacific, B. bazarutense Gilchrist from Mosambique, B. tattersalli Hubbs from Ceylon and Madras and B. minucauda (Whitley) from Qucensland, Australia, can hardly be distinguished from both $B$. belcheri and $B$. belcheri var. tsingtauense on the data respectively given by Gilchrist (1923), Azariah (1965) and Whitley (1932). B. lanceolatum is seemingly, however, distinguished, though not very clearly, from $B$. belcheri according to the measurements given by Webb (1956b, 1957), especially by its smaller number of both the total myotomes and the dorsal fin-ray chambers. Nevertheless, the opinion of Tattersall (see p. 142) may still be worthy of re-examination from various points of views and on further specimens from much more different localities in the world seas.

\section{REFERENGES}

Ali, M.Y. and Lindsey, G.C. 1974. Heritable and temperature-induced meristic variation in the medaka, Orizias latipes. Can. J. Zool., 52: 959-976.

Andrews, E.A. 1895. An amphioxus from Japan. Zool. Znz., 18: 57-60.

Anno, K. and Kawai, Y. 1975. Mucopolysaccharides from the connective tissues of the amphioxus, Branchiostoria belcherii. Comp. Biochem. Physiol. B, 52: 547-549.

Anonym. 1890. On the several kinds of animals dredged off Shikanoshima early in April. Zool. Mag. Tokyo, 2: 269-270. (In Japanese) 
Azariah, J. 1965. Studies on the cephalochordates of Madras coast. Taxonomic study. J. Mar. Biol. Ass. India, 7: 348-363.

Azuma, S. 1904. Animals in the Ariake Sea (A new locality for "Nameküit-ito"). Zool. Mag. Tokyo, 16: 182-186. (In Japanese)

Bone, Q. 1957. The problem of the 'amphioxides' larva. Nature, Lond., 180: 1462-1464.

1958. Observations upon the living larva of amphioxus. Pubbl. Staz. Zool. Napoli, 30 458-471.

Boring, A.M. and Li, H.-L. 1932. Is the chinese amphioxus a separate species? Peking Nat. Hist. Buli., 6 (3): 9-18.

Boschung, H.V. and Gunter, G. 1962. Distribution and variation of Branchiostoma caribaeum in Mississippi Sound. Tulane Studies in Zoology, 9: 245-257.

Chin, T.G. 1941. Studies on the biology of Amoy amphioxus, Branchiostoma belcheri Gray. Phil. Jour. Sci., 75: 369-424.

Colombera, D. 1974. Male chromosomes in two populations of Branchiostoma lanceolatum. Experientia, 30: 353-355.

Fowler, J.A. 1970. Control of vertebral number in teleosts-an embryological problem. Quart. Rev. Biol., 45: 148-167.

Fran7, V. 1922. Systematische Revision der Akranier. Yena. Zeit. Nat. Wiss., 58: 369-452.

Fujitani, O. 1910. A new locality for "Namekuji-uo"? Zool. Mag. Tokyo, 22: 357-358. (In Japanese)

Gilchrist, J.D.F. 1923. A new species of amphioxus from the Bazaruto Islands (Branchiostoma bazarutense). Ann. Mag. Nat. Hist., ser. 9, 12: 62-65.

Gray, J.E. 1847. Description of a new species of Amphioxus from Borneo. Proc. Zool. Soc. Lond., 15: 35-36.

Hubbs, C.L. 1922a. A list of the lancelets of the world with diagnoses of five new species of Branchiostoma. Occ. Pap. Mus. Zool., Univ. Michigan, 4 (105): 1-16.

1922b. Variations in the number of vertebrae and other meristic characters of fishes correlated with the temperature of the water during development. Am. Nat., 56: 360-372.

1924. Seasonal variation in the number of vertebrae of fishes. Pap. Mich. Acad. Sci., Arts and Latters, 2: 207-214.

1926. The structural consequences of modifications of the developmental rate in fishes, considered in reference to certain problems of evolution. Am. Nat., 60: 57-81.

Ijima, I. 1918. A Manual of Zoology. $950+30$ pp. Dainihon Insatsu Co., Ltd., Tokyo. (In Japanese)

Jordan, D.S. and Synder, J.O. 1901. A review of the lancelets, hag-fishes, and lampreys of Japan, with a description of two new species. Proc. U.S. Nat. Mus., 23: 725-734.

Jordan, D.S., Tanaka, S. and Snyder, J.O. 1913. A catalogue of the fishes of Japan. Jour. Coll. Sci. Imp. Univ. Tokyo, 33: 1-497.

Kataoka, S. 1900. "Namekuji-uo". Zool. Mag. Tokyo, 12: 416. (In Japanese)

Kataoka, F. and Fujita, H. 1974. The occurrence of endocrine cells in the intestine of the lancelet, Branchiostoma japonicum. An electron microscope study. Arch. Histol. Jap., 36: 401-406.

Kikuchi, T. 1977. Ecological distribution of macrobenthos and shell remains off Tsuyazaki, Fukuoka Prefecture. Benthos Research, 13/14: 1-10. (In Japanese)

Kirkaldy, J.W. 1895. A revision of the genera and species of the Branchiostomidae. Quart. J. Microsc. Sci., 37: 303-323.

Kobayashi, S. 1910. A new locality for "Namekuji-uo". Zool. Mag., Tokyo, 22: 166-167. (In Japanese)

Kobayashi, H. 1979. Hypophysis. 138 pp. (UP Biology Series) Univerity Press of Tokyo, Tokyo. (do.)

Kumada, T. 1936. On the two world-famous localities of the lancelets in the East. Zool. Mag., Tokyo, $48: 179-180$. (do.)

Lönnberg, E. 1901. Leptocardii. In Broon, H.G., Klassen und Ordnungen des Tier-reichs, 6(1): 99249.

Lou, T.-H. 1936. Note sur la larve d'Amphioxus recueillie a Tchefou. Cont. Inst. Zool. Nat. Acad. Peiping, 3: 115-121.

Makino, S. 1950. A review of the chromosome numbers in animals. $213 \mathrm{pp}$. Hokuryukan, Tokyo (In Japanese) 
Massé, H. 1964. Contribution a l'étude des céphalocordés de la côte occidentale de Madagascar. Rec. Trav. St. Mar. End., fasc. 51 (Bull. 35): 269-273.

Matsubara, K. 1955. Fish morphology and hierarchy. 1605 pp. Ishizaki Shoten, Tokyo. (In Japanese)

Nakagawa, H. 1897. Notes on an amphioxus obtained in Amakusa, Kyusyu. Annot. Zool. Jap., 1 : $125-132$.

Nakamura, S. 1890. Brief notes on the animals dredged off Shikanoshima. Zool. Mag., Tokyo, 2: 409-410. (In Japanese)

Nakao, T. 1964. On the fine structure of the amphioxus photoreceptor. Tohoku J. Exp. Med., 82: 349-372.

1965. The excretory organ of Amphioxus (Branchiostomia belcheri). Journ. Ultrastruc. Res., 12: 1-12.

Nishikawa, T. 1978. Short report on the lancelet Branchiostoma belcheri (Gray) newly found from Tanabe Bay, Japan. Nankiseibutu, 20: 39-40. (In Japanese)

Nogusa, S. 1957. The choromosomes of the Japanese lancelet, Branchiostoma belcheri (Gray), with special reference to the sex-chromosome. Annot. Zool. Jap., 30: 42-46.

Ogura, K. 1895. Some animals collected from Shikanoshima. Zool. Mag., Tokyo, 7: 71-72. (In Japanese)

Ohshima, H. 1927. On "Namekuji-uo" and Lingula in the Ariake Sea. Zool. Mag., Tokyo, 39: 306309. (do.)

Oka, A. 1895. Amphioxus from Japan. Zool. Mag., Tokyo, 7: 132-133. (do.)

Okada, Y. 1929. A survey on the bottom fauna and flora around Japan. Zool. Mag., Tokyo, 41 : 296-297. (do.)

Okada, Y., Uchida, K. and Matsubata, K. 1935. Illustrated catalogue of fishes in Japan. $425+46 \mathrm{pp}$. Sanseido, Tokyo. (do.)

Oyama, J. and Yoshii, N. 1940. On "Namekuji-uo" from the Ariake sea. Zool. Mag., Tokyo, 52 (2): 60. (do.)

Prashad, B. 1934. On a collection of Indian cephalochordates, with notes on the species from the Indian waters in the Indian Museum, Calcutta. Rec. Indian Mus., 36: 329-334.

Sakata, T. 1939. On the collection of "Namekuji-uo". Collecting and Breeding, 1: 7. (In Japanese)

Shojima, Y. 1974. On Branchiostoma belcheri (Gray) from the East China Sea. Seikai Reg. Fish. Lab., News, 18: 4-7. (do.)

Tanaka, S. 1915. A new locality for "Namekuji-uo". Zool. Mag., Tokyo, 27: 414. (do.) 1916. One more new locality for "Namekuji-uo". Zool. Mag., Tokyo, 28: 323. (do.)

1927. Cephalochordata. In "Illustrated Encyclopedia of the Fauna of Japan". Hokuryukan, Tokyo. p. 481 . (do.)

Takachiho, N. 1895. Short communication (no title). Zool, Mag., Tokyo, 7: 200. (do.)

Tattersall, W.M. 1903. Notes on the classification and geographical distribution of the cephalochordata. Proc. Trans. Liverpool Biol. Soc., 17: 269-302.

Tchang-Si and Koo, K.-G. 1936. Description of a new variety of Branchiostoma belcheri (Gray) from Kiaochow Bay, Shantung, China. Contr. Inst. Zool. Nat. Acad. Peiping, 3: 77-114.

Tokioka, T. 1947. Cephalochordata. In "Illustrated Encyclopedia of the Fauna of Japan, Revised edition." Hokuryukan, Tokyo. p. 530. (In Japanese)

1965. Cephalochordata. In "New Illustrated Encyclopedia of the Fauna of Japan". Hokuryukan, Tokyo. pt. 3, p. 135. (In Japanese)

Tsukiyama, Y. 1902. On the marine animals from Amakusa. Zool. Mag., Tokyo, 14: 336-341. (do.)

Wakayama Pref. 1978. Annual report on the environmental conditions in Wakayama Prefecture (1978). (do.)

Webh, J.E. 1956a. A note on the lancelets of Singapore, with a description of a new species of Branchiostoma. Proc. Zool. Soc. Lond., 127: 119-123.

1956b. On the population of Branchiostoma lanceulatum and their relations with the West African lancelets. Proc. Zool. Soc. Lond., 127: 125-140.

- 1956c. Cephalochordata. Sci. Rep. "John Murray" Exped., 10: 121-128.

1957. On the lancelets of South and East Africa. Ann. S. Afr. Mus., 43: 249-270. 
Whitley, G.P. 1932. The lancelets and lampreys of Australia. Aust. Zool., 7: 256-264.

Wickstead, J.H. and Bone, Q. 1959. Ecology of acraniate larvae. Nature, Lond., 184: 1849-1851.

Wickstead, J.H. 1964. On the status of the "amphioxides" larva. Journ. Linn. Soc. Lond., 45: 201-207.

1975. Chordata: Acrania (Cephalochordata). In Giese, A.C. and Pearse, J.S. (eds.) "Reproduction of marine invertebrates", $2: 283-319$.

Willey, A. 1897. Zoological observations in the South Pacific-On a new amphioxus from the Louisiade Archipelago (Asymmetron caudatum n. sp.). Quart. J. Miscrosc. Sci. (N. S.), 39: 219-222.

Yatsu, N. 1901. A new locality for "Namekuji-uo". Zool. Mag., Tokyo, 13: 38. (In Japanese) 1904. Amphioxus collected from Gogoshima Island. Zool. Mag., Tokyo, 16: 282-283. (do.) 1909. On "Namekuji-uo" at Tomo, Seto Inland Sea. Zool. Mag., Tokyo, 21: 493. (do.)

P.S.: The following important paper reached the author after the manuscript had been sent to the editorial board of the journal.

Carandang, N.C. (1978). The lancelets (Cephalochordata, Amphioxi) of Lucena Anchorage, Quezon, Philippines. Kalikasan, 7 (2): 177-186, 2 tabls., 3 figs.

In this paper, measurements are given on 191 specimens of $B$. belcheri collected in 1969-72 from the intertidal or immediate subtidal zone of Lucena Anchorage, Quezon, and they are summarized as follows: 1,266-398 $(321.09 \pm 20.66) ; 2,44-111$ $(81.76 \pm 10.44) ; 3,2.0-7.0(3.84 \pm 0.95) ; 4,2.5-18.3(11.20 \pm ?) ; 5,0.35-0.67(0.46 \pm$ $0.048) ; 6,30-44(38.16 \pm 2.59) ; 7,11-21(16.54 \pm 1.20) ; 8,7-13(10.32 \pm 1.35) ; 9$, $50-75(64.89 \pm 4.22) ; 10,15-46$; for 1-10, see the explanation of Table 2.

This datum is seemingly considerably different in several characters from the previous records given in Table 3, and to be noticed from the viewpoint of the geographical variation in this species. 